Nihal Doğruöz-Güngör, Elif Özlem Arslan-Aydoğdu, Emrah Dirmit, and Ender Usuloğlu. Anthropogenic impacts on the bacterial profile of Yarik Sinkhole in Antalya, Turkey. Journal of Cave and Karst Studies, v. 82, no. 2, p. 116-124. DOI:10.4311/2019MB0147

\title{
ANTHROPOGENIC IMPACTS ON THE BACTERIAL PROFILE OF YARIK SINKHOLE IN ANTALYA, TURKEY
}

\author{
Nihal Doğruöz-Güngör ${ }^{1, ~ c}$, Elif Özlem Arslan-Aydoğdu', Emrah Dirmit², and Ender Usuloğlu ${ }^{3}$
}

\begin{abstract}
Yarık Sinkhole is a vertical cave with a length of $1378 \mathrm{~m}$ and depth of $533 \mathrm{~m}$. Its location was marked by The Anatolian Speleology Association in 2011, and expedition entries started in 2014. Yarık Sinkhole became the $12^{\text {th }}$ deepest cave of Turkey. The aim of this study was to determine the bacterial profile of the Yarık Sinkhole using next generation metagenomic sequencing and to investigate whether the bacterial profile of the cave is affected by the activities of people living in this region. This study is important as the samples were collected during the first entrance of the exploration of the cave (up to $300 \mathrm{~m}$ ). The samples were collected from depths of $-80 \mathrm{~m},-120 \mathrm{~m}$ and $-300 \mathrm{~m}$. A total of 33 OTUs (Operational Taxonomic Unit) contained 4 bacteria phyla. Only Firmicutes, Proteobacteria and Actinobacteria phyla comprised a mean abundance of more than $1 \%$ in each sample. However, 18 different species have been detected in the Yarık Sinkhole. The most predominant species are Acinetobacter Iwoffii, Methylobacterium tardum, and Propionibacterium acnes. Although the sampling was done during the first exploration of the Yarık Sinkhole, the fact that the majority of bacteria found in the cave are human-associated, suggest serious impacts from people living near this cave from runoff with human and animal waste and trash.
\end{abstract}

\section{Introduction}

Caves are a subsurface habitat that are not explored as much with regard to biodiversity and community composition because of some environmental and geographical limitations. Natural caves generally involve an ecosystem that has a high humidity, limited nutritional sources, and a usually stable temperature, which are stable characteristics of a natural laboratory in terms of bacteria and their metabolic processes. Such environments are habitats only to those microorganisms that are specialized for the conditions in question. Therefore, natural caves are recognized as extreme environments (Palmer, 1991; Northup and Lavoie, 2001; Tomczyk-Żak and Zielenkiewicz, 2016). Microbial communities in caves are often highly variable dependent on the microenvironment. The range of bacterial diversity and composition are determined to be related to the geochemistry of host rocks (Barton et al., 2007). Nutrients also contribute to cave microbial diversity. Organic matter and microorganisms could be carried in to caves by air currents, seepage water, floods, seasonality, and animal/human activities (Shabarova et al., 2013).

The most appropriate way to unearth the bacterial diversity of a cave is to perform sampling at the time of exploration of the cave. Thus, the original microbiological diversity of the cave can be more realistically discovered by sampling before contamination associated with the cavers. However, the conditions may vary depending on the location and surroundings of the caves in terms of human impacts. Numerous cave microbiology studies have been carried out in the world. Since each cave is unique, these studies do not lose their importance (Busquets et al., 2014; De Mandal et al., 2014; Herzog Velikonja et al., 2014; Kieraite-Aleksandrova et al., 2015; Riquelme et al., 2015; Leuko et al., 2017).

It is estimated on the basis of the studies conducted in karstic areas that there are approximately 40,000 caves in Turkey (General Directorate of Mineral Research and Exploration). Cave microbiology studies from Turkish cave include: Yücel and Yamaç (2007), investigated the antimicrobial activity of Streptomyces spp. isolates from 19 different caves. In addition, characterization and definition of bacteria contributing to the formation of dripstone in Yıldızkaya cave systems in Erzurum have been studied by Barış (2009). Gulecal-Pektas and Temel (2017) studied the bacterial diversity and taxonomic composition of the Oylat Cave in Bursa and the Kaklık Cave in Denizli with poor oxygen, high temperature, and sulfur conditions. Even though the number of studies on microbiology in the caves of Turkey has been increasing, these studies are insufficient when the estimated number of caves is taken into account.

The culture technique is not sufficient on its own for determining the microbiological diversity of a cave. The rate of culturable bacteria in environments that contain complex microorganisms is only $0.1-1 \%$ of the total number due to their specific nutritional requirements (Torsvik and Øvreas, 2002). With the application of molecular methods, it was revealed that nutrient-poor caves had a surprisingly rich bacterial diversity. Metagenomics is a technique to access far more microbial diversity directly from environmental samples. Next-generation sequencing is cost-effective and provi-

${ }^{1}$ Istanbul University, Faculty of Science, Department of Biology, 34134 Vezneciler, Istanbul, Turkey

${ }^{2}$ Koza Gold Operations Company, 06370 Batıkent, Ankara

${ }^{3} 49$ Street Bradford Unit 2 Watertown Massachusetts USA

cCorresponding author: Nihal Doğruöz-Güngör ndogruoz@istanbul.edu.tr 
des more detailed taxonomic profiles between samples to be determined (Nelson el al., 2014). It has been shown that some microorganisms isolated by using culture methods were not detected by the molecular methods, and vice versa, which it has demonstrated that cultivation methods remain critical in microbial diversity studies (Donachie et al. 2007).

The Yarık Sinkhole is one of the caves which differ by its location in environmental conditions. During the summer months, the presence of people who are living there, as well as those who practice animal husbandry (approximately 30-50 people and 400 animals) are noticed. There are also tiny siphons where waters join the cave at both the main entrance of the Yarık Sinkhole and at different points deeper into the cave. In this study, we collected soil samples from three different points of the first-explored part of the cave, to both examine the bacteria profile, and, by means of the next-generation sequencing method, showed the impact of the anthropogenic effects on the cave's bacterial diversity.

\section{Site Description}

\section{Geology}

Yarık Sinkhole (GPS coordinate: UTM 448068.47 E 4036006.77 N) is located on the Sivastı Plateau that is centered $30 \mathrm{~km}$ north of Gazipaşa (Fig. 1) and is named with a specially-assigned geological sequence as the Sivastı formation. This formation, which is 2000-meters high, is one of the parts of the Taşeli Plateau.The study area, thought to be from the earliest Triassic age, has a complex structure with various orogenic movements such as Hershey and Alpen that undergo bending and fracturing. There are stratified schists and limestones at the Sivastı formation. Due to the different physical characteristics of the lithology, the schists are more curled and the limestones are more broken (Ulu, 1983).

A cross-sectional view of the cave map placed on the topography is presented in Figure 2. Yarık Sinkhole has a total length of $1378 \mathrm{~m}$ and $533 \mathrm{~m}$ depth. The first entrance to the cave was explored up to a depth of $300 \mathrm{~m}$ (Fig. 3). In 2016, the cave discovery reached a depth of $533 \mathrm{~m}$. Yarık Sinkhole became the 12th deepest cave of Turkey. The entrance to the cave has a wide mouth created by fracture hence its name; Yarık in Turkish means fracture (Fig.4). The watershed of the Yarık Sinkhole is a closed valley where the main rock is limestone with little sediment on the basin of the valley. There is no vegetation except for some trees planted by villagers for shade.

Despite a wide opening, there are occasional narrow passages in the cave and a rapid downward descent is characteristic of this cave. When the cross section map of the cave is viewed after the bench, downward declination

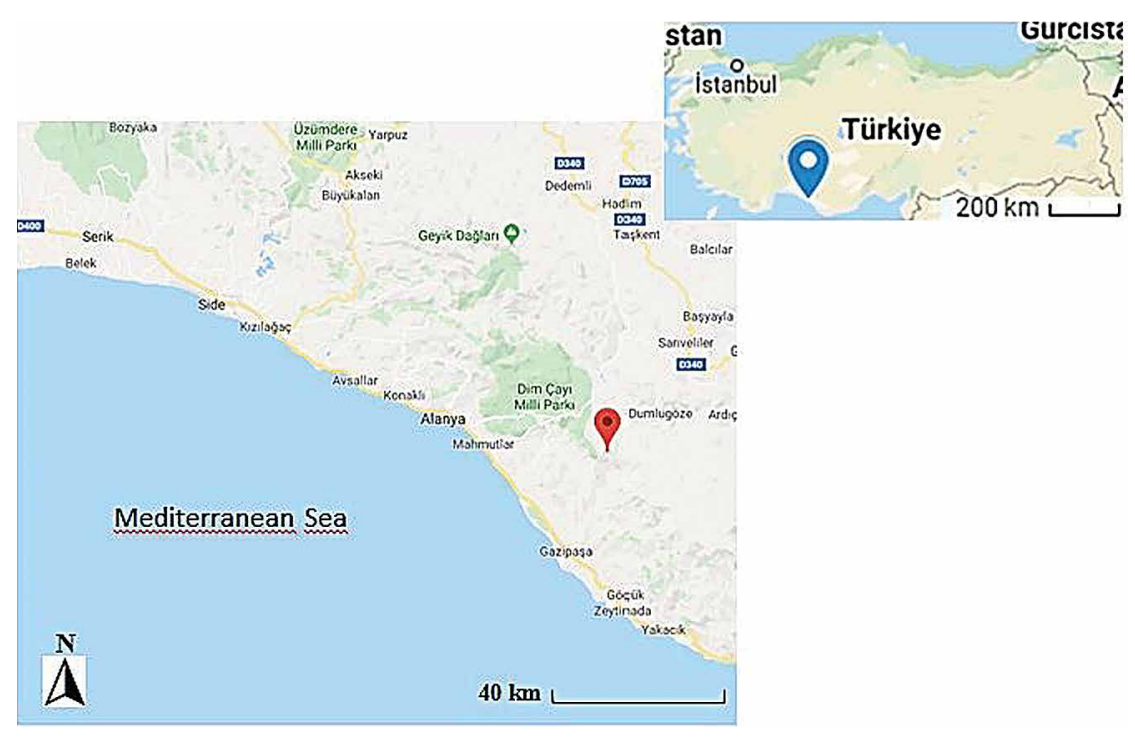

Figure 1. Yarık sinkhole location source [Google (Googlemaps, 2019)]. slowly gives away to horizontal passages with small ponds and lakes in them. The resulting bench size ranges from $5 \mathrm{~m}$ to $40 \mathrm{~m}$ on average. These benches generally formed as a result of active faults and fractures developed over time. The Yarık Sinkhole ceiling is high generally, but some of the narrow passages are difficult to pass, especially in the case of a flood when these passages will be totally blocked. Unlike most vertical caves, in the Yarık Sinkhole speleothems such as flowstones and cave pearls are found in the horizontal portion.

However, there are not any attempts to enter the entrance of the Yarık Sinkhole by the villagers as it will be fatal since the entrance is an 80 -meter shaft. Water only flows during the melting of ice in the spring. The cave camp area is 50-meters away from the entrance in a small pasture surrounded with seasonal settlements. The area is filled up with ice and snow in winter and in spring time meltwater is siphoned through a small pit with sediment at the bottom. The waste of livestock also goes along with the water.

The impact of population can be explained by the settlers in that valley. Additional side galleries within Yarık Sinkhole carry water from other watershed areas where there are additional people. Even though the impact cannot be measured, it is evident by the garbage that we have found deep in the cave which can not come only from the main entrance. 

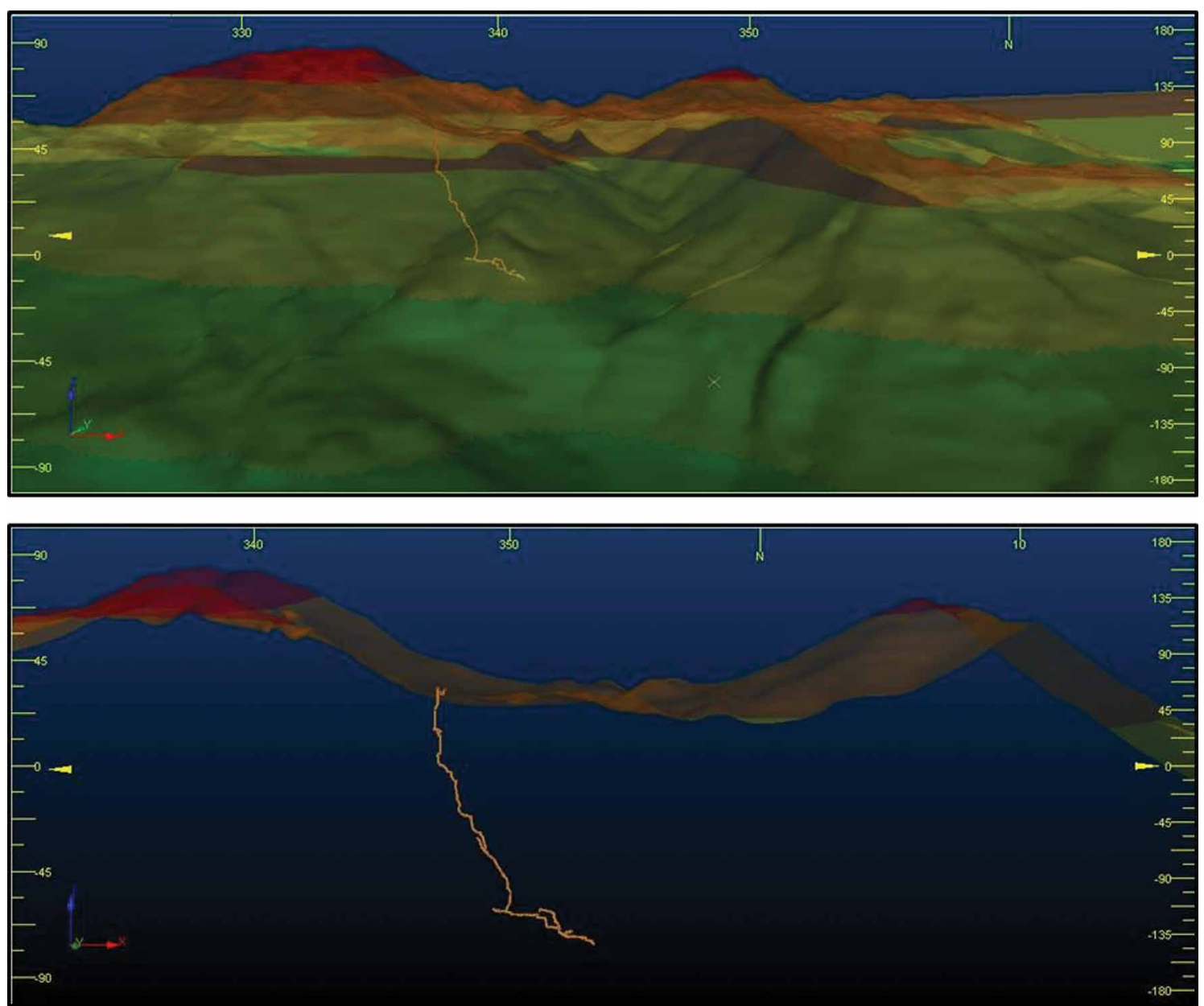

Figure 2. Cross-section view of topography (a) and Yarık Sinkhole's map (b) from The Anatolian Speleology Association(ASPEG).

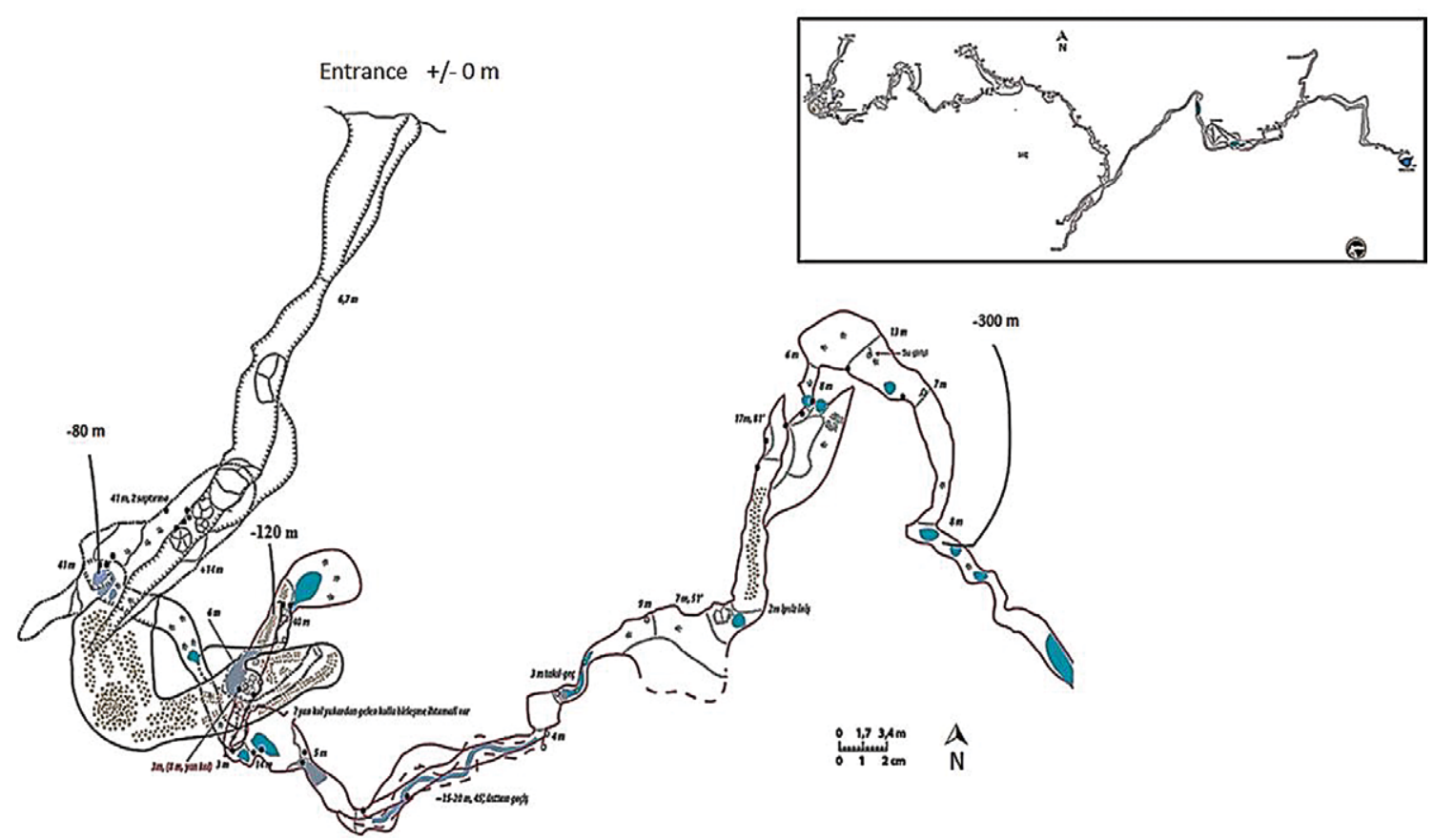

Figure 3. Plan and profile of Yarık Sinkhole and sampling points from the Anatolian Speleology Association (ASPEG).
MATERIALS AND METHODS

Sampling and Physical-chemical analysis

The soil samples were taken from depths of $-80 \mathrm{~m},-120 \mathrm{~m}$ in June 2014 and $-300 \mathrm{~m}$ in August 2014, in parallel with the exploration of the cave. Approximately 10 $\mathrm{g}$ of soil was collected aseptically for microbial analysis from each sampling site in the cave. The samples were maintained at $4{ }^{\circ} \mathrm{C}$ and transported within 24 hours to the laboratory. The temperature and humidity of the sampling area were measured by a portable Temperature/ Humidity Meter (TFA 31.1028).

The water sample was taken in a pool from Yarık Sinkhole (-100 m depth) for hydrochemical characteristics in June 2014. The chemical analysis $\left(\mathrm{HCO}_{3}{ }^{-}, \mathrm{F}^{-}, \mathrm{Ca}^{2+}\right.$, $\mathrm{Cl}^{-}, \mathrm{Mg}^{2+}, \mathrm{K}^{+}, \mathrm{Na}^{+}$, and $\mathrm{SO}_{4}{ }^{2-}$ ) of the water sample were carried out according to different standard methods (Table 1) (APHA, 1992). 


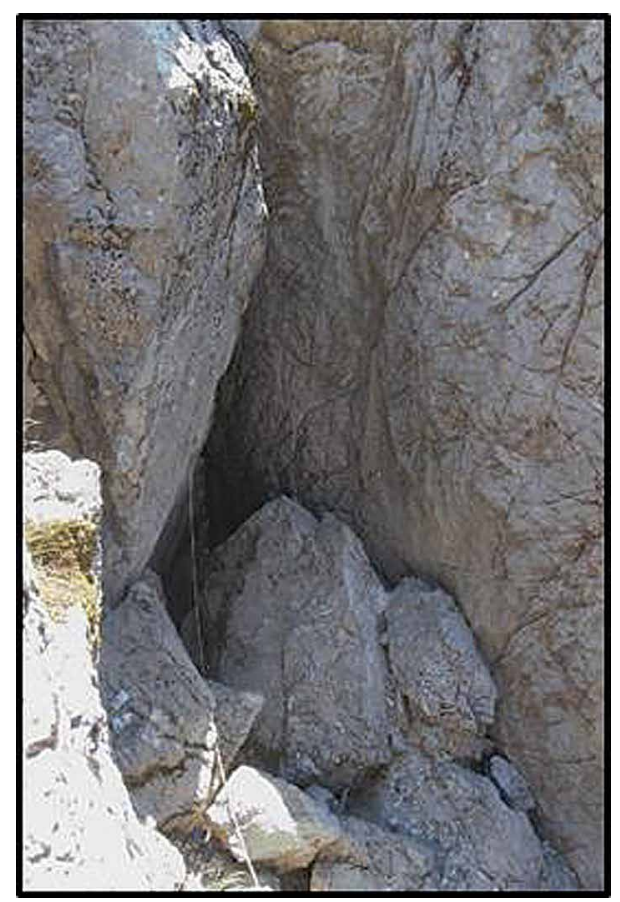

Figure 4. Yarık Sinkhole Entrance (about 10-meters long and 5-meters wide).

\section{DNA extraction}

DNA was extracted from $0.3 \mathrm{~g}$ (wet weight) of soil by using the Fast DNA Spin Kit for soil from Q-Biogene (Heidelberg, Germany) according to the manufacturer's instructions.

\section{S rRNA Metagenomic Sequencing Library Preparation and Sequenc- ing}

The microbial diversity at three depths was evaluated by using the Illumina MiSeq next generation sequencing approach (Novogene). The protocol includes the primer pair sequences for the $\mathrm{V} 3$ and $\mathrm{V} 4$ region of the 16S rRNA that create a single amplicon of approximately $460 \mathrm{bp}$ (Klindworth et al., 2013). The protocol also includes overhang adapter sequences that must be appended to the primer pair sequences for compatibility with Illumina index and sequencing adapters. Illumina adapter overhang nucleotide sequences-16S rRNA specific sequences were 5'TCGTCGGCAGCGTCAGATGTGTATAAGAGACAG-CCTACGGGNGGCWGCAG-3' for the forward primer and 5'-GTCTCGTGGGCTCGGAGATGTGTATAAGAGACAG-GACTACHVGGGTATCTAATCC-3' for the reverse primer. The first PCR was performed using BiospeedyTM Proof Reading DNA Polymerase 2x Reaction Mix (Bioeksen Ltd Co., Turkey) and $200 \mathrm{~nm}$ of each primer. The following program was performed on Biorad CFX Connect Instrument (Bio-Rad Laboratories, U.S.A.): $95^{\circ} \mathrm{C}$ for 3 minutes; 25 cycles of $95^{\circ} \mathrm{C}$ for 30 seconds, $55^{\circ} \mathrm{C}$ for 30 seconds and $72^{\circ} \mathrm{C}$ for 30 seconds; $72^{\circ} \mathrm{C}$ for 5 minutes. The PCR product was run on an agarose gel to verify the size ( $550 \mathrm{bp})$ and purified using BiospeedyTM PCR Product Purification Kit (Bioeksen Ltd. Co., Turkey).

The dual indices and Illumina sequencing adapters were attached to the purified first PCR products via the second PCR that was run using the Nextera XT Index Kit (Illumina Inc., USA) and the following program: $95^{\circ} \mathrm{C}$ for 3 minutes; 8 cycles of $95^{\circ} \mathrm{C}$ for 30 seconds, $55^{\circ} \mathrm{C}$ for 30 seconds and $72^{\circ} \mathrm{C}$ for 30 seconds; $72^{\circ} \mathrm{C}$ for 5 minutes. The PCR products were purified using BiospeedyTM PCR Product Purification Kit (Bioeksen Ltd. Co., Turkey). The final library was run on a Bioanalyzer DNA 1000 chip to verify the size ( 630 bp). The final library was diluted using $10 \mathrm{mM}$ Tris pH 8.5 to $4 \mathrm{nM}$ and the $5 \mu \mathrm{L}$ aliquots were mixed for pooling the libraries. In preparation for cluster generation and sequencing, pooled libraries were denatured with $\mathrm{NaOH}$, diluted with hybridization buffer $(\mathrm{HT} 1)$, and then heat denatured before MiSeq sequencing. Illumina MiSeq v3 reagent kits were used for the runs. Each run included a minimum of $5 \%$ PhiX to serve as an internal control.

\section{Bioinformatic Analysis}

The raw sequence data (concatenated forward and reverse sequence reads) were cleaned, reduced, and analyzed using Mothur Version 1.36.1. First, the barcode and the primer sequences were trimmed and then unique sequences were identified. The trimmed unique sequences were aligned to the SILVA rRNA database sequences using blastn algorithm (Pruesse et al., 2007). Before this the SILVA database sequences were trimmed to include only the V3-V4 region. The overhangs at both ends were removed via filtering the sequences and the redundancy check was carried out. For further de-nosing, the sequences were pre-clustered. The chimeras were eliminated using the implanted code UCHIME (Edgar et al., 2011). The sequences were classified by using Bayesian classifier implanted in Mothur. The reference and taxonomy files were adopted from the SILVA database (Pruesse et al., 2007). After Operational Taxonomic Unit (OTU) picking and their taxonomic assignment using the SILVA rDNA database, the OTUs were binned into phylotypes.

\section{Sequence Accession Numbers}

The raw sequencing data generated in this study were deposited into the NCBI database under accession numbers SRP123547 in the NCBI Sequence Read Archive, with the following accession numbers: SRS2657311, SRS2657312, and SRS2657313.

\section{Results}

\section{Physical-chemical environment}

The chemical characteristic of the water sample is presented in Table 1. The concentration in $\mathrm{Ca}^{2+}$ was found to exceed that of $\mathrm{Mg}^{+}$, whereby the predominant anion was determined to be $\mathrm{HCO}_{3}^{-}$. The mean air temperature and humidity inside the Yarık Sinkhole were $12.4^{\circ} \mathrm{C}$ and $94 \%$ respectively. 
Table 1. Parameters and test methods for chemical analysis of the Yarık Sinkhole water.

\begin{tabular}{|c|c|c|c|c|}
\hline Parameter & Unit & $\begin{array}{l}\text { Yarık Sinkhole } \\
\text { Water Sample }\end{array}$ & Test Method & Reference \\
\hline $\mathrm{HCO}_{3}^{-}$ & $\mathrm{mg} / \mathrm{L}$ & 124 & SM 2320 B & APHA (1992) \\
\hline $\mathrm{F}^{-}$ & $\mathrm{mg} / \mathrm{L}$ & 0.25 & SM 4500-F D & APHA (1992) \\
\hline $\mathrm{Ca}^{2+}$ & $\mathrm{mg} / \mathrm{L}$ & 35.7 & EPA 200.7 & APHA (1992) \\
\hline $\mathrm{Cl}^{-}$ & $\mathrm{mg} / \mathrm{L}$ & 5 & $\mathrm{SM} 4500 \mathrm{Cl}^{-} \mathrm{B}$ & APHA (1992) \\
\hline $\mathrm{Mg}^{2+}$ & $\mathrm{mg} / \mathrm{L}$ & 7.22 & EPA 200.7 & APHA (1992) \\
\hline $\mathrm{Na}+$ & $\mathrm{mg} / \mathrm{L}$ & 1.96 & EPA 200.7 & APHA (1992) \\
\hline $\mathrm{K}+$ & $\mathrm{mg} / \mathrm{L}$ & 0.74 & EPA 200.7 & APHA (1992) \\
\hline $\mathrm{SO}_{4}^{2-}$ & $\mathrm{mg} / \mathrm{L}$ & 15.5 & $\mathrm{SM} 4500 \mathrm{SO}_{4}^{-2} \mathrm{E}$ & APHA (1992) \\
\hline $\mathrm{pH}$ & $\cdots$ & 7.42 & TS EN ISO 10523 & TSE (1999) \\
\hline Conductivity & $\mu S / \mathrm{cm}$ & 222 & TS 9748 EN 27888 & TSE (1996) \\
\hline
\end{tabular}

Bacterial taxonomy and distribution

Taxonomic assignment of 130,703 sequencing reads (Phred score $\geq 30$; Mean read length $>300 \mathrm{bp}$ ) from Yarık Sinkhole was obtained by targeting the $\mathrm{V} 3$ and $\mathrm{V} 4$ region of the bacterial $16 \mathrm{~S}$ rRNA gene. A total of 33 OTUs (based on $97 \%$ cutoff) comprising 4 bacterial phyla were found. The variation of the fractions of the phyla according to the depths was shown in (Table 2). Only Firmicutes, Proteobacteria,

and Actinobacteria phyla had a mean abundance of more than $1 \%$ in each sample holding more than $98 \%$ of the total sequence reads. The bacterial phylum with the highest presence percentage is Proteobacteria (average $80 \%$ ) at all the depths. It is followed by Actinobacteria (average 16\%). While the rate of presence of Firmucutes is more than $5 \%$ at $-300 \mathrm{~m}$, it is smaller than $1 \%$ at other depths. Bacteroidetes were found at less than $1 \%$ at other depths (Table 2 ).

At the class level, Gammaproteobacteria (average 17\%) was present at all the depths. Alphaproteobacteria (average $24 \%$ ), Actinobacteria (average 17\%), Bacilli (average 2\%) and Bacteroidia (average $0.3 \%$ ) were also observed at all

Table 2. Relative abundance (\%) of the detected species and phyla.

\begin{tabular}{|c|c|c|c|}
\hline \multirow[b]{2}{*}{ Phyla and Species } & \multicolumn{3}{|c|}{ Sampling Depth, m } \\
\hline & -80 & -120 & -300 \\
\hline Firmicutes (phylum) & 0.552 & 0.848 & $5.550^{a}$ \\
\hline Bacteroidetes (phylum) & 0.005 & 0.006 & 0.918 \\
\hline Actinobacteria (phylum) & 0.807 & $10.264^{a}$ & $39.484^{\mathrm{a}}$ \\
\hline Proteobacteria (phylum) & $98.636^{a}$ & $88.882^{a}$ & $54.048^{a}$ \\
\hline Alphaproteobacteria (class) & $6.513^{a}$ & $16.552^{\mathrm{a}}$ & $49.186^{a}$ \\
\hline Gammaproteobacteria (class) & $92.124^{\mathrm{a}}$ & $72.255^{a}$ & $4.861^{\mathrm{a}}$ \\
\hline Betaproteobacteria (class) & 0.000 & 0.075 & 0.000 \\
\hline Methylobacterium tardum & $6.505^{a}$ & $16.511^{\mathrm{a}}$ & $49.179^{a}$ \\
\hline Propionibacterium acnes & 0.743 & $10.225^{a}$ & $38.144^{a}$ \\
\hline Acinetobacter Iwoffii & $91.621^{\mathrm{a}}$ & $72.238^{a}$ & $4.852^{\mathrm{a}}$ \\
\hline Bacillus thermoamylovorans & 0.039 & 0.036 & $4.212^{\mathrm{a}}$ \\
\hline Streptococcus sanguinis & 0.508 & 0.002 & $1.125^{a}$ \\
\hline Porphyromonas spp. & 0.005 & 0.006 & 0.918 \\
\hline Rothia mucilaginosa & 0.015 & 0.015 & 0.908 \\
\hline Rhodococcus spp. & 0.002 & 0.024 & 0.271 \\
\hline Aeribacillus geobacillus pallidus & 0.000 & 0.002 & 0.203 \\
\hline Micrococcus luteus & 0.000 & 0.000 & 0.159 \\
\hline Acinetobacter johnsonii & 0.503 & 0.017 & 0.009 \\
\hline Bacillus spp. & 0.000 & 0.000 & 0.007 \\
\hline Methylobacterium fujisawaense & 0.002 & 0.015 & 0.005 \\
\hline Staphylococcus pasteuri & 0.005 & 0.807 & 0.002 \\
\hline Sulfitobacter sp. & 0.000 & 0.024 & 0.002 \\
\hline Solirubrobacter spp. & 0.047 & 0.000 & 0.002 \\
\hline Simonsiella muelleri & 0.000 & 0.075 & 0.000 \\
\hline Methylobacterium radiotolerans & 0.005 & 0.002 & 0.000 \\
\hline
\end{tabular}

a Taxonomic group with an abundance higher than $1 \%$. the depths, except for $-80 \mathrm{~m}$ and -300 $\mathrm{m}$, where Betaproteobacteria were absent. In total, 18 species were identified at 3 different depths. Only 9 of these bacteria were found to constitute $5 \%$ or more. The frequency of Acinetobacter Iwoffii, Methylobacterium tardum, and Propionibacterium acnes were the ones with the highest presence. Other species were determined to be in lower percentages (Table 2).

\section{Discussion}

Caves are special due to their formation processes and their chemical nature, are also unique in terms of microbial diversity. When exposed to human activity, caves lose their microbial richness (Lavoie and Northup, 2005; Ikner et al., 2007; Chelius et al., 2009). For this reason, studies carried out by taking samples especially during first entry and from isolated environments aim to better understand the microbiota. For cave microbiology studies, it can be said that horizontal caves are preferred because of ease of sampling compared to vertical caves. For similar reasons, the cave microbiology studies in Turkey have focused on the horizontal caves (Gulecal-Pektas, 2016; Gulecal-Pektas and Temel, 2015; Gulecal-Pektas and Temel, 2017; Candıroğlu, 2018).

This study is the first microbiological research conducted in a vertical cave in Turkey with sampling during the first 
discovery of the cave. Anthropogenic impact is expected to be unlikely for the microorganism profile in the samples taken at the time of the initial exploration of vertical caves. These previously cited reasons made our study original and also important for its intended purpose. However, the area surrounding the Yarik Sinkhole area and entrance is cluttered with summer houses of villagers that live on the lower levels of the mountains. During periods of late April to late September, villagers migrate to these settlements and use the surroundings for pasture of their livestock of cows, sheep, and especially goats. These settlements do not have infrasturcture for toiletry and waste water. All of the liquid waste goes into opened pits and from there seeps to the underground. They use the entrance of Yarik Sinkhole as garbage disposal which we had to intervene, warning them to stop throwing rubbish that includes baby diapers to rubber cycle tires, etc. There are several siphons connected to the sink from such areas that suggest anthropogenic impacts on the Yarık Sinkhole. Our study aimed to evaluate the bacterial diversity of the Yarik Sinkhole and to show possible anthropogenic impacts on diversity.

The Yarık Sinkhole resembles most cave systems with its high level of humidity and stable air temperature (Riquelme et al., 2015; Lavoie et al., 2017; Leuko et al., 2017). Similar to our findings, Leuko et al., (2017) reported a higher Ca ${ }^{2+}$ concentration than that of $\mathrm{Mg}^{+}$as a result of the chemical analysis of the water samples from the Su Betu limestone cave in Sardinia, Italy, and detected $\mathrm{HCO}_{3}{ }^{-}$as the predominant anion. Reasearchers conclued that the predominancy of $\mathrm{HCO}_{3}{ }^{-}$found in a cave indicates a calcium-bicarbonate type cave. On the other hand, the high level of $\mathrm{SO}_{4}{ }^{2-}$ detected in the water sample from the Yarık Sinkhole may indicate an oxidation of the sulphur minerals contained in the rocks in contact with the water. $\mathrm{pH}$, presence of nutrients, light, oxygen, sulphur, and compounds of other metals all affect the growth and structure of microbial communities in a humid cave. A change in those conditions can cause the differences in the composition of species (Engel et al., 2010; Jones and Bennett, 2014).

In the curent study, the phyla and their percentages present at $-80 \mathrm{~m},-120 \mathrm{~m}$ and $-300 \mathrm{~m}$ depths of Yarık Sinkhole were determined with next generation sequencing (NGS). We detected Proteobacteria, Actinobacteria, Firmicutes, and Bacteroidetes phyla. The most predominant two phyla have been found to be Proteobacteria (average $80 \%$ ) and Actinobacteria (average 16\%). The dominant groups in caves vary by the characteristics of caves (Lee et al., 2012). The major phyla found as a result of metagenomic analysis of soil samples taken from 5 caves in the Ozark Cave system are Proteobacteria (27.7\%), Acidobacteria (17.3\%), Actinobacteria (12.2\%), Firmicutes (8.2\%), Chloroflexi (8.1\%), Bacteroidetes (8\%), and Nitrospirae (6\%) (Oliveira et al., 2017). In another study, the most dominant phyla determined as a result of metagenomic analysis of sediment samples of 3 caves in Mizoram (India) were Actinobacteria (35.9\%), Chloroflexi (13.9\%), Planctomycetes (13.7\%), Acidobacteria (11.44\%), and Proteobacteria (6.6\%) (De Mandal et al., 2014). Members of the Proteobacteria and Actinobacteria phyla, dominant in both our study and many other studies, are well-adapted to growth with limited nutrients (Jurado et al., 2010; Lee et al., 2012; Barton, 2015; Wiseschart et al., 2018).

Despite the undeniable dominance of Proteobacteria in cave ecosystems, the representation of the Proteobacteria classes varies in different environments. At the class level, Gammaproteobacteria was present at all the depths, as were Alphaproteobacteria, Actinobacteria, Bacilli and Bacteroidia. Betaproteobacteria was detected only at $-120 \mathrm{~m}$ depth. Proteobacteria is a cosmopolitan bacterial group that is common and abundant (Laiz et al.,1999; Zhaou et al., 2007). Members of the Proteobacteria phylum have the abilities of utilizing different organic compounds, the fixation of atmospheric carbon, and nitrogen transformation (Tomczyk-Zak and Zielenkiewicz, 2016). It is also suggested that dominance of Proteobacteria is a result of the increasing organic input caused by cave visitors (Ikner et al., 2007). In the current study among the Proteobacteria, $92 \%, 72 \%$, and $5 \%$ were recognized in the class of Gammaproteobacteria, $6.5 \%, 16.5 \%$ and $49 \%$ as Alphaproteobacteria at $-80 \mathrm{~m},-120 \mathrm{~m}$ and $-300 \mathrm{~m}$ depths respectively. Similarly, it was determined that there were plenty of Gammaproteobacteria in soil samples taken from the Mangoo-Pee cave. $23 \%$ of the Proteobacteria found by $43 \%$ in soil sample of the Blowing Spring Cave was determined as Gammaproteobacteria, $19 \%$ as Alphaproteobacteria, and $1 \%$ as Betaproteobacteria (Barron et al., 2010).

Another dominant group, Actinobacteria, is known for being able to develop in environments containing limited nutrients, to degrade different humic material, and to dissolve phosphate and calcium carbonate (Ball et al., 1989; Dari et al., 1995; Laiz et al., 1999). It was reported that this phylum existed in cave walls, soil, sediment, and on speleothem surfaces, and it was suggested that it might have considerably contributed to the formation of the cave structures and the biomineralization in the cave ecosystem (Cuezva et al., 2012; Ortiz et al., 2013; Tomczyk-Zak and Zielenkiewicz, 2016).

Even though microorganism diversity differs by the method used (culture-depend or culture- independed), by the sampling area, and by the sample type (soil, cave wall, speleothem surface, etc.), the core phyla reported in previous cave studies are Proteobacteria and Actinobacteria (Groth et al., 1999; Tomczyk-Żak and Zielenkiewicz, 2016). Besides these, the presence frequency of the Firmicutes, Acidobacteria, Bacteroidetes, Chloroflexi, and Planctomycetes phyla in caves is at a considerable rate (Youssef and Elshahed, 2008; Jurado et al., 2010; Lee et al., 2012; Barton, 2015; Wiseschart et al., 2018). 
The evaluation of the NGS results of our study shows low diversity (only 18 species were identified through metagenomics) compared to other studies. The ingress of the waters contaminated by human/animal wastes into the Yarık Sinkhole can be one of the reasons. The microorganisms and organic substances that enter the cave from outside via contamination might negatively influence the cave's ecosystem leading in turn to the irreversible loss of its native biodiversity (Ikner et al., 2007; Chelius et al., 2009).

On the other hand, in the study conducted by Yasir (2018), 13 strains were identified by the culture method and a few genera, including Bacillus, Microbacterium, Pseudomonas, and Psychrobacter, were determined by the pyrosequencing analysis. However, in the pyrosequencing data Carnobacterium, Exiguobacterium, Paucisalibacillus and Fictibacillus were not detected. In addition, studies have shown that low abundance bacteria can be captured by culture methods (Lagier et al., 2012; Shade et al., 2012; Stefani et al., 2015). For this reason, the bacterial diversity of the environment should be determined more accurately by combining the culture methods with series based studies such as 16S rRNA gene analysis and metagenomics. Although there are some commonalities among the groups detected by using culture and molecular techniques, microorganism groups obtained through molecular results are richer since they also contain nonculturable groups as well. The results change in accordance with the characteristics of each cave (Engel et al., 2010; Jurado et al., 2010; Jones et al., 2012; Lee et al., 2012; Barton, 2015). However, when results are evaluated on the basis of species, variations in bacterial diversity of each cave become more obvious.

In the present study, Methylobacterium, Acinetobacter, Propionibacterium, and Bacillus were found more than other genera. It is known that these bacteria can utilize a wide variety of carbon sources and play an important role in calcification (Hiraishi et al., 1995; Cacchio et al., 2004; Portillo et al., 2008; Busquets et al., 2014). Propionibacterium acnes and Acinetobacter Iwoffii can really get an advantage in vivo from polyphosphate as an energy reserve and they may use it during periods of starvation or unfavorable conditions (Van Groenestijn et al., 1987; Chen, 1999). A. Iwoffii, $P$. acnes, and Streprococcus sanguinis that were found at $1 \%$ or higher in at least one of the sampled depths cause diseases such as bacteremia, pulmonary infections, meningitis, sepsis, pneumonia, bacterial endocarditis, and periodontal diseases (Doughari et al., 2011; Baker et al., 2018; Achermann et al., 2014). Also A. Iwoffii is a normal flora of the oropharynx and the skin in approximately $25 \%$ of healthy individuals (Regalado et al., 2009). According to research conducted by the Human Microbiome Project the bacteria of the genera Consortium Lactobacillus, Propionibacterium, Streptococcus, Bacteroides, Corynebacterium, Staphylococcus, Moraxella, Haemophilus, Prevotella, and Veillonella are of human origin (Huttenhower et al. 2012). Leuko et al., (2017) detected a high level of $P$. acnes in their study conducted in the Su Bentu limestone cave in Sardinia, Italy, and associated that result with human contamination. To our knowledge, all of the bacteria that were found in the samples collected from Yarık Sinkhole were previously found in caves, except for Sulfitobacter (Busquets et al., 2014; De Mandal et al., 2014; Herzog Velikonja et al., 2014; Kieraite-Aleksandrova et al., 2015; Riquelme et al., 2015; Leuko et al., 2017).

The achievement of sampling in parallel to the discovery of the Yarık Sinkhole separates this study from other cave microbiology studies to a significant extent. Analysis of the samples showed that the bacterial diversity is limited and the detected bacteria are generally originated from humans. These results show that anthropogenic activities around a vertical cave such as the Yarık Sinkhole cause contamination of the cave.

\section{Acknowledgements}

This work was supported by thelstanbul University Scientific Project Unit (BAP Project No: FBA-2017-24145). The Anatolian Speleology Association are acknowledged for their assistance in sampling.

\section{References}

Achermann, Y., Goldstein, E.J., Coenye, T., and Shirtliff M.E., 2014, Propionibacterium acnes: from commensal to opportunistic biofilm-associated implant pathogen: Clinical Microbiology Reviews, v. 27, no. 3, p. 419-440. https://doi.org/ 10.1128/CMR.00092-13.

APHA, 1992, Standard Methods for Examination Water and Wastewater, 17th ed. Am. Publ. Hlth Assoc.,Washington, D.C.

Baker, S.P., Nulton, T.J., and Kitten, T., 2018, Genomic, phenotypic, and virulence analysis of Streptococcus sanguinis oral and infective endocarditis isolates: Infection and Immunity, v. 87, no. 1, p. 1-18. https://doi.org/ 10.1128/IAI.00703-18.

Ball, A.S., Betts, W.B., and Mccarthy, A.J., 1989, Degradation of lignin-related compounds by actinomycetes: Applied and Environmental Microbiology, v. 55, p. 1642-1644.

Barron, S.K., Murdock, C.A., Blair, B.G., Meade, M.E., and Barger, T.W., 2010, Analysis of bacterial diversity in soils from Blowing Spring Cave (Lauderdale County, AL): The Journal of the Alabama Academy of Science, v. 81, p. 1-10.

Barton, H.A., 2015, Starving artists: Bacterial oligotrophic heterotrophy in caves: in Life in Extreme Environments: Microbial Life of Cave Systems, Ed. A. Engel, Walter DeGruyter, Berlin, Germany, p. 79-95.

Barton, H.A., Taylor, N.M., Kreate, M.P., Springer, A.C., Oehrle, S.A., and Bertog, J.L., 2007, The impact of host rock geochemistry on bacterial community structure in oligotrophic cave environments: International Journal of Speleology, v. 36, p. 93-104. http://dx.doi.org/10.5038/1827-806X.36.2.5.

Busquets, A., Fornós, J.J., Zafra, F., Lalucat, J., and Merino, A., 2014, Microbial communities in a coastal cave: Cova des Pas de Vallgornera (Mallorca, Western Mediterranean): International Journal of Speleology, v. 43, p, 205-216. https://doi.org/ 10.5038/1827-806X.43.2.8. 
Cacchio, P., Contento, R., Ercole, C., Cappuccio, G., Martinez, M.P., and Lepidi, A., 2004, Involvement of microorganisms in the formation of carbonate speleothems in the Cervo Cave (L'Aquila-Italy): Geomicrobiology Journal, v. 21, no. 8, p. 497-509. https://doi. org/10.1080/01490450490888109.

Candiroglu, B., 2018, Antimicrobial component productivity and antibiotic resistance of bacteria isolated from a cave [M.S. thesis]: Istanbul, Istanbul University. https://tez.yok.gov.tr/UlusalTezMerkezi/tezSorguSonucYeni.jsp

Chelius, M.K., Beresford, G., Horton, H., Quirk, M., Selby, G., Simpson, R.T., Horrocks, R., and Moore, J.C., 2009, Impacts of alterations of organic inputs on the bacterial community within the sediments of Wind Cave, South Dakota, USA: International Journal of Speleology, v. 38, p. 1-10. http://dx.doi.org/10.5038/1827-806X.38.1.1.

Chen, K.Y., 1999, Study of polyphosphate metabolism in intact cells by 31-P nuclear magnetic resonance spectroscopy. in Inorganic Polyphosphates, Ed. Schröder, H.C., Müller, W.E.G, Springer, Berlin, Heidelberg. p. 253-273. https://doi.org/10.1007/978-3-642-58444-2_13.

Cuezva, S., Fernandez-Cortes, A., Porca, E., Pašić, L., Jurado, V., Hernandez-Marine, M., Serrano-Ortiz, P., Hermosin, B., Cañaveras, J.C., Sanchez-Moral, S., and Saiz-Jimenez C., 2012, The biogeochemical role of actinobacteria in Altamira cave, Spain: FEMS Microbiology Ecology, v.81, no.1, p. 281-290. https://doi.org/10.1111/j.1574-6941.2012.01391.x.

Dari, K., Bechet, M., and Blondeau, R., 1995, Isolation of soil Streptomyces strains capable of degrading humic acids and analysis of their peroxidase-activity: FEMS Microbiology Ecology, v. 16, p. 115-121. https://doi.org/10.1016/0168-6496(94)00075-8.

De Mandal, S., Sanga, Z., and Nachimuthu, S.K., 2014, Metagenomic analysis of bacterial community composition among the cave sediments of Indo-Burman biodiversity hot spotregion: PeerJ Preprints, 2: e631v1. https://doi.org/10.7287/peerj.preprints.631v1.

Donachie, S.P., Foster, J. S., and Brown, M.V., 2007, Culture clash: challenging the dogma of microbial diversity: The ISME Journal, v.1, no.2, p. 97-99. https://doi.org/10.1038/ismej.2007.22

Doughari, H.J., Ndakidemi, P.A., Human, I.S., and Benade S., 2011, The ecology, biology and pathogenesis of Acinetobacter spp.: an overview: Microbes and Environments, v. 26, no. 2, p. 101-112. https://doi.org/10.1264/jsme2.me10179.

Edgar, R.C., Haas, B.J., Clemente, J.C., Quince, C., and Knight, R., 2011, UCHIME improves sensitivity and speed of chimera detection: Bioinformatics, v. 27, no. 16, p. 2194-2200. https://doi.org/10.1093/bioinformatics/btr381.

Engel, A.S., Meisinger, D.B., Porter, M.L., Payn, R.A., Schmid, M., Stern, L.A., Schleifer, K.H., and Lee N.M., 2010, Linking phylogenetic and functional diversity to nutrient spiraling in microbial mats from Lower Kane Cave (USA): The ISME journal, v. 4, no. 1, p. 98-110. https://doi. org/ 10.1038/ismej.2009.91.

General Directorate of Mineral Research and Exploration. http://www.mta.gov.tr/ v3.0/ arastirmalar/ magara-envanteri [accessed: July 28, 2017].

Groth, I., Vettermann, R., Schuetze, B., Schumann, P., and Saiz-Jiménez, C., 1999, Actinomycetes in karstic caves of Northern Spain (Altamira and Tito Bustillo): Journal of Microbiological Methods, v. 36, p. 115-122.

Gulecal-Pektas, Y., 2016, Bacterial diversity and composition in Oylat Cave (Turkey) with combined sanger/pyrosequencing approach: Polish Journal of Microbiology, v. 65, no. 1, p. 69-75. https://doi.org/ 10.5604/17331331.1197277.

Gulecal-Pektas, Y., and Temel, M., 2015, Determination of microbial diversity in moonmilk deposits with next generation sequencing: Fresenius Environmental Bulletin, v. 24, no. 3, p. 825-832.

Gulecal-Pektas, Y., and Temel, M., 2017, A window to the subsurface: microbial diversity in hot Ssprings of a sulfidic cave (Kaklik, Turkey): Geomicrobiology Journal, v. 34, no. 4, p. 374-384. https://doi.org/10.1080/01490451.2016.1204374.

Herzog Velikonja, B., Tkavc, R., and Pašić, L., 2014, Diversity of cultivable bacteria involved in the formation of macroscopic microbial colonies (cave silver) on the walls of a cave in Slovenia: International Journal of Speleology, v. 43, p. 45-56. https://doi.org/10.5038/1827-806x.43.1.5.

Hiraishi, A., Furuhata, K., Matsumoto, A., Koike, K.A., Fukuyama, M., and Tabuchi, K., 1995, Phenotypic and genetic diversity of chlorine resistant Methylobacterium strains isolated from various environments: Applied and Environmental Microbiology, v. 61, p. $2099-2107$.

Huttenhower, C., Gevers, D., Knight, R., Abubucker, S., Badger, J.H., Chinwalla, A.T., Creasy, H.H., Earl, A.M., FitzGerald, M.G., Fulton, R.S., Giglio, M.G., Hallsworth-Pepin, K., Lobos, E.A., Madupu, R., Magrini, V., Martin, J.C., Mitreva, M., Muzny, D.M., Sodergren, E.J., Versalovic, J., Wollam, A.M., Worley, K.C., Wortman, J.R., Young, S.K., Zeng, Q., Aagaard, K.M., Abolude, O.O., Allen-Vercoe, E., Alm, E.J., Alvarado, L., Andersen, G.L., Anderson, S., Appelbaum, E., Arachchi, H.M., Armitage, G., Arze, C.A., Ayvaz, T., Baker, C.C., Begg, L., Belachew, T., Bhonagiri, V., Bihan, M., Blaser, M.J., Bloom, T., Bonazzi, V., Brooks, J.P., Buck, G.A., Buhay, C.J., Busam, D.A., Campbell, J.L., Canon, S.R., Cantarel, B.L., Chain, P.S.G., Chen, I.A., Chen, L., Chhibba, S., Chu, K., Ciulla, D.M., Clemente, J.C., Clifton, S.W., Conlan, S., Crabtree, J., Cutting, M.A., Davidovics, N.J., Davis, C.C., DeSantis, T.Z., Deal, C., Delehaunty, K.D., Dewhirst, F.E., Deych, E., Ding, Y., Dooling, D.J., Dugan, S.P., Dunne, W.M., Durkin, A.S., Edgar, R.C., Erlich, R.L., Farmer, C.N., Farrell, R.M., Faust, K., Feldgarden, M., Felix, V.M., Fisher, S., Fodor, A.A., Forney, L.J., Foster, L., Francesco, V.D., Friedman, J., Friedrich, D.C., Fronick, C.C., Fulton, L.L., Gao, H., Garcia, N., Giannoukos, G., Giblin, C., Giovanni, M.Y., Goldberg, J.M., Goll, J., Gonzalez, A., Griggs, A., Gujja, S., Haake, S.K., Haas, B.J., Hamilton, H.A., Harris, E.L., Hepburn, T.A., Herter, B., Hoffmann, D.E., Holder, M.E., Howarth, C., Huang, K.H., Huse, S.M., Izard, J., Jansson, J.K., Jiang, H., Jordan, C., Joshi, V., Katancik, J.A., Keitel, W.A., Kelley, S.T., Kells, C., King, N.B., Knights, D., Kong, H.H., Koren, O., Koren, S., Kota, K.C., Kovar, C.L., Kyrpides, N.C., La Rosa, P.S., Lee, S.L., Lemon, K.P., Lennon, N., Lewis, C.M., Lewis, L., Ley, R.E., Li, K., Liolios, K., Liu, B., Liu, Y., Lo, C.C., Lozupone, C.A., Lunsford, R.D., Madden, T., Mahurkar, A.A., Mannon, P.J., Mardis, E.R., Markowitz, V.M., Mavromatis, K., McCorrison, J.M., McDonald, D., McEwen, J., McGuire, A.L., McInnes, P., Mehta, T., Mihindukulasuriya, K.A., Miller, J.R., Minx, P.J., Newsham, I., Nusbaum, C., O'Laughlin, M., Orvis, J., Pagani, I., Palaniappan, K., Patel, S.M., Pearson, M., Peterson, J., Podar, M., Pohl, C., Pollard, K.S., Pop, M., Priest, M.E., Proctor, L.M., Qin, X., Raes, J., Ravel, J., Reid, J.G., Rho, M., Rhodes, R., Riehle, K.P., Rivera, M.C., Rodriguez-Mueller, B., Rogers, Y.H., Ross, M.C., Russ, C., Sanka, R.K., Sankar, P., Sathirapongsasuti, J.F., Schloss, J.A., Schloss, P.D., Schmidt, T.M., Scholz, M., Schriml, L., Schubert, A.M., Segata, N., Segre, J.A., Shannon, W.D., Sharp, R.R., Sharpton, T.J., Shenoy, N.,. Sheth, N.U., Simone, G.A., Singh, I., Smillie, C.S., Sobel, J.D., Sommer, D.D., Spicer, P., Sutton, G.G., Sykes, S.M., Tabbaa, D.G., Thiagarajan, M., Tomlinson, C.M., Torralba, M., Treangen, T.J., Truty, R.M., Vishnivetskaya, T.A., Walker, J., Wang, L., Wang, Z., Ward, D.V., Warren, W., Watson, M.A., Wellington, C., Wetterstrand, K.A., White, J.R., Wilczek-Boney, K., Wu, Y., Wylie, K.M., Wylie, T., Yandava, C., Ye, L., Ye, Y., Yooseph, S., Youmans, B.P., Zhang, L., Zhou, Y., Zhu, Y., Zoloth, L., Zucker, J.D., Birren, B.W., Gibbs, R.A., Highlander, S.K., Methé, B.A., Nelson, K.E., Petrosino, J.F., Weinstock, G.M., Richard K. Wilson,R.K. and White, O., 2012, Structure, function and diversity of the healthy human microbiome: Nature, v. 486, no.7402, p. 207-214. https://doi.org/10.1038/nature11234.

Ikner, L.A., Toomey, R.S., Nolan, G., Neilson, J.W., Pryor, B.M., and Maier, R.M., 2007, Culturable microbial diversity and the impact of tourism in Kartchner Caverns, Arizona: Microbial Ecology, v. 53, p. 30-42. https://doi.org/ 10.1007/s00248-006-9135-8.

Jones, A.A., and Bennett, P.C., 2014, Mineral microniches control the diversity of subsurface microbial populations: Geomicrobiology Journal, v. 31, no. 3, p. 246-261. https://doi.org/10.1080/01490451.2013.809174.

Jones, D.S., Albrecht, H.L., Dawson, K.S., Schaperdoth, I., Freeman, K.H., Pi Y., Pearson, A., and Macalady, J.L., 2012, Community genomic analysis of an extremely acidophilic sulfur-oxidizing biofilm: The ISME Journal, v. 6, p. 158-170. https://doi.org/ 10.1038/ismej.2011.75.

Jurado, V., Laiz, L., Rodriguez-Nava, V., Boiron, P., Hermosin, H., Sanchez-Moral S., and Saiz-Jimenez, C., 2010, Pathogenic and opportunistic microorganisms in caves: International Journal of Speleology, v.39, p. 15-24. https://doi.org/ 10.5038/1827-806X.39.1.2. 
Kieraite-Aleksandrova, I., Aleksandrovas, V., and Kuisiene, N., 2015, Down into the Earth: microbial diversity of the deepest cave of the world: Biologia, v. 70, no. 8, p. 989-1002. https://doi.org/ 10.1515/biolog-2015-0127.

Klindworth, A., Pruesse, E., Schweer, T., Peplles, J., Quast, C., Horn, M., and Glöckner, F.O., 2013, Evaluation of general 16S ribosomal RNA gene PCR primers for classical and next-generation sequencing-based diversity studies: Nucleic Acids Research, v. 41, no. 1, p. 1-11. https:// doi.org/10.1093/nar/gks808.

Laiz, L., Groth, I., Gonzalez, I., and Saiz-Jimenez, C., 1999, Microbiological study of the dripping waters in Altamira Cave (Santillana del Mar, Spain): Journal of Microbiological Methods, v. 36, p. 129-138.

Lagier, J.C., Armougom, F., Million, M., Hugon, P., Pagnier, I., Robert, C., Bittar, F., Fournous, G., Gimenez, G., Maraninchi, M., Trape, J.F., Koonin, E.V., La Scola, B., and Raoult, D., 2012, Microbial culturomics: paradigm shift in the human gut microbiome study: Clinical Microbiology and Infection, v. 18, no. 12, p.1185-1193. https://doi.org/10.1111/1469-0691.12023.

Lavoie, K.H., Winter, A.S., Read, K.J., Hughes, E.M., Spilde, M.N., and Northup, D.E., 2017, Comparison of bacterial communities from lava cave microbial mats to overlying surface soils from Lava Beds National Monument, USA: PloS One, v. 12, no. 12, e0169339. doi:10.1371/journal.pone.0169339

Lee, I.T., Liu, J.Y., Lin, C.H., Oyama, K.I., Chen, C.Y., and Chen, C.H., 2012, Ionospheric plasma caves under the equatorial ionization anomaly: Journal of Geophysical Research, v. 117, no. A11309, p. 1-9. https://doi.org/10.1029/2012JA017868.

Leuko, S., Koskinen, K., Sanna, L., D’Angeli, I.M., De Waele, J., Marcia, P., Moissl-Eichinger, C., and Rettberg, P., 2017, The influence of human exploration on the microbial community structure and ammonia oxidizing potential of the Su Bentu limestone cave in Sardinia, Italy: PLoS One, v. 12, no. 7, p. 1-22. https://doi.org/10.1371/journal.pone.0180700.

Nelson, M.C., Morrison, H.G., Benjamino, J., Grim, S.L., and Graf, J., 2014, Analysis, optimization and verification of illumina-generated 16S rRNA gene amplicon surveys: PLoS One, v. 9, no. 4-e94249, p. 1-14. https://doi.org/10.1371/journal.pone.0094249.

Northup, D.E., and Lavoie, K.H., 2001, Geomicrobiology of caves: a review: Geomicrobiology Journal, v. 18, p. 199-222. https://doi. org/10.1080/01490450152467750.

Oliveira, C., Gunderman, L., Coles, C.A., Lochmann, J., Parks, M., Ballard, E., Glazko, G., Rahmatallah, Y., Tackett, A.J., and Thomas, D.J., 2017, 16 S rRNA gene-based metagenomic analysis of Ozark Cave bacteria: diversity, v. 9, no. 3, p. 1-16. https://doi.org/10.3390/d9030031.

Ortiz, M., Legatzki, A., Neilson, J.W., Fryslie, B., Nelson, W.M., Wing, R.A., Soderlund, C.A., Pryor, B.M., and Maier, R.M., 2014, Making a living while starving in the dark: metagenomic insights into the energy dynamics of a carbonate cave: The ISME Journal, v. 8, no. 2, p. 478-491. https://doi.org/10.1038/ismej.2013.159.

Palmer, A.N., 1991, Origin and morphology of limestone caves: Geological Society of America Bulletin, v. 103, p. 1-21. https://doi.org/10.1130/00 16-7606(1991)103<0001:OAMOLC>2.3.CO;2

Portillo, M.C., Gonzalez, J.M., and Saiz-Jimenez, C., 2008, Metabolicallyactive microbial communities of yellow and grey colonizations on the walls of Altamira Cave, Spain: Journal of Applied Microbiology, v. 104, p. 681-691. https://doi.org/ 10.1111/j.1365-2672.2007.03594.x.

Pruesse, E., Quast, C., Knittel, K., Fuchs, B.M., Ludwig, W., Peplies, J., and Glöckner, F.O., 2007, SILVA: a comprehensive online resource for quality checked and aligned ribosomal RNA sequence data compatible with ARB: Nucleic Acids Research, v. 35, no. 21, p. 7188-7196. https:// doi.org/10.1093/nar/gkm864.

Regalado, N.G., Martin, G., and Antony, S.J., 2009, Acinetobacter /woffii: bacteremia associated with acute gastroenteritis: Travel Medicine and Infectious Disease, v. 7, no. 5, p. 316-317. https://doi.org/10.1016/j.tmaid.2009.06.001.

Riquelme, C., Marshall Hathaway, J.J., Enes Dapkevicius, M.L.N., Miller, A.Z., Kooser, A., Northup, D.E., Jurado, V., Fernandez, O., Saiz-Jimenez, C., and Cheeptham N., 2015, Actinobacterial diversity in volcanic caves and associated geomicrobiological interactions: Frontiers in Microbiology, v. 6, no. 1342, p. 1-16. https://doi.org/ 10.3389/fmicb.2015.01342.

Shabarova, T., Widmer, F., and Pernthaler, J., 2013, Mass effects meet species sorting: transformations of microbial assemblages in epiphreatic subsurface karst water pools: Environmental Microbiology, v. 15, no. 9, p. 2476-2488. https://doi.org/10.1111/1462-2920.12124.

Shade, A., Hogan, C.S., Klimowicz, A.K., Linske, M., McManus, P.S., and Handelsman, J., 2012, Culturing captures members of the soil rare biosphere: Environmental Microbiology, v. 14, no. 9, p. 2247-2252. https://doi.org/ 10.1111/j.1462-2920.2012.02817.x

Stefani, F.O., Bell, T.H., Marchand, C., Ivan, E., El Yassimi, A., St-Arnaud, M., and Hijri, M., 2015, Culture-dependent and-independent methods capture different microbial community fractions in hydrocarbon-contaminated soils: PLoS One, v. 10, no. 6-e0128272, p. 1-16. https://doi. org/10.1371/journal.pone.0128272.

Tomczyk-Żak, K., and Zielenkiewicz, U., 2016, Microbial diversity in caves: Geomicrobiology Journal, v. 33, p. 20-38. https://doi.org/10.1080/014 90451.2014.1003341.

Torsvik, V., and Øvreås, L., 2002, Microbial diversity and function in soil: from genes to ecosystems: Current Opinion in Microbiology, v. 5, no. 3, p. 240-245.

TSE., 1996 TS 9748 EN 27888: Water quality—determination of electrical conductivity: Turkish Standard Institution, Ankara

TSE., 1999, TS 3263 ISO 10523: Water quality—determination of pH: Turkish Standard Institution, Ankara

Ulu, Ü., 1983, Sugözü-Gazipaşa (Antalya) Alanının Jeoloji İncelemesi: Jeoloji Mühendisliği Dergisi, v. 7, no. 1, p. 3-10.

Van Groenestijn, J.W., Deinema, M.H., and Zehnder, A.J., 1987, ATP production from polyphosphate in Acinetobacter strain 210A: Archives of Microbiology, v. 148, no. 1, p. 14-19. https://doi.org/10.1007/bf00429640.

Wiseschart, A., Mhuanthong, W., Thongkam, P., Tangphatsornruang, S., Chantasingh, D., and Pootanakit, K., 2018, Bacterial diversity and phylogenetic analysis of type II polyketide synthase gene from Manao-Pee Cave, Thailand: Geomicrobiology Journal, v. 35, no. 6, p. 518-527. https://doi.org/10.1080/01490451.2017.1411993.

Yasir, M., 2018, Analysis of bacterial communities and characterization of antimicrobial strains from cave microbiota: Brazilian Journal of Microbiology, v. 49, no. 2, p. 248-257. https://doi.org/10.1016/j.bjm.2017.08.005.

Youssef, N.H., and Elshahed, M.S., 2008, Diversity rankings among bacterial lineages in soil: The ISME Journal, v. 3, p. 305-313. https://doi. org/10.1038/ismej.2008.106.

Zhou, J., Gu, Y., Zou, C., and Mo, M., 2007, Phylogenetic diversity of bacteria in an earth-cave in Guizhou Province, Southwest of China: Journal of Microbiology, v. 45, p. 105-112. 